\title{
A midiatização e suas lógicas: análise de casos à luz dos regimes de interação e sentido
}

\section{Conrado Moreira Mendes}

Pontifícia Universidade Católica de Minas Gerais, Departamento de Comunicação Social, Belo Horizonte, MG, Brasil

ORCID: http://orcid.org/0000-0002-3721-8578

\section{Maria Ângela Mattos}

Pontifícia Universidade Católica de Minas Gerais, Departamento de Comunicação Social, Belo Horizonte, MG, Brasil

ORCID: http://orcid.org/0000-0002-0764-6846

\section{Mariana Vitti}

Pontifícia Universidade Católica de Minas Gerais, Departamento de Comunicação Social, Belo Horizonte, MG, Brasil

ORCID: http://orcid.org/0000-0003-3499-3576

\section{Marcelle Primo}

Pontifícia Universidade Católica de Minas Gerais, Departamento de Comunicação Social, Belo Horizonte, MG, Brasil

ORCID: http://orcid.org/0000-0002-4042-2529

\section{André Vianna Maricato}

Pontifícia Universidade Católica de Minas Gerais, Departamento de Comunicação Social, Belo Horizonte, MG, Brasil

ORCID: http://orcid.org/0000-0003-4347-8525

\section{Ranier Alves}

Pontifícia Universidade Católica de Minas Gerais, Departamento de Comunicação Social, Belo Horizonte, MG, Brasil

ORCID: http://orcid.org/0000-0002-6229-4468

\section{Resumo}

O objetivo do artigo é analisar as possíveis articulações entre os regimes de interação e sentido e as perspectivas da midiatização e suas lógicas, a primeira centrada na lógica do funcionamento da mídia e a segunda inscrita nos processos sociais em sua imbricação com processos de midiatização, denominada de lógicas da midiatização. A partir de estudos de casos empíricos à luz dos quatro regimes de interação formulados pelo sociossemioticista Eric Landowski (2014) programação, manipulação, ajustamento e acidente - buscamos ampliar o quadro interpretativo acerca dos processos de 
interação midiatizada por meio da interface entre aquelas perspectivas da midiatização e da sociossemiótica no contexto da sociedade midiatizada contemporânea.

\section{Palavras-chave}

Lógicas da mídia. Lógicas da midiatização. Regimes de interação e sentido. Sociossemiótica.

\section{Introdução}

A proposta do artigo é analisar casos empíricos presentes no cenário da midiatização e a manifestação de suas lógicas, considerando, para isso, a perspectiva sul-americana da midiatização, com ênfase às contribuições brasileiras de José Luiz Braga $(2006,2015,2016)$ e Antonio Fausto Neto $(2008,2010)$, e a sociossemiótica. Desta última, advêm os regimes de interação e sentido formulados por Eric Landowski (2014) - programação, manipulação, ajustamento e acidente - que são tomados como um quadro interpretativo abrangente, levando em conta a dinâmica das interações no contexto do processo de constituição da sociedade em midiatização e a manifestação de suas diferentes lógicas. Essa proposta, portanto, pretende promover um diálogo entre perspectivas sobre a midiatização e a sociossemiótica.

Partimos do pressuposto de que a concepção da lógica da midiatização diz respeito a processos sociocomunicacionais mais amplos, complexos e plurais do que as lógicas da mídia, fundadas no funcionamento da sociedade dos meios. Se, por um lado, as lógicas da mídia ou midiáticas são caracterizadas por um conjunto de processos empresariais, profissionais e tecnológicos institucionalizados na sociedade dos meios; por outro, as lógicas da midiatização são acionadas por indivíduos, grupos, setores e instituições socioculturais que produzem e experimentam outras lógicas presentes na sociedade em vias de midiatização, indo além dos processos interacionais já estabelecidos pelos aparatos técnicomidiáticos.

Nesse sentido, além de serem construídas social e historicamente e não limitadas às práticas estabelecidas pelos campos midiático e mercadológico, as lógicas da midiatização correspondem a um espectro amplo e diversificado de processos interacionais, permeados por dimensões temporais e espaciais da comunicação, que incluem “[...] alternativas entre o midiatizado e o presencial, suas incidências mútuas, os processos de transformação e as articulações em suas múltiplas variantes [...]” (BRAGA, 2015, p. 26). 
Este trabalho estrutura-se em três itens de discussão. 0 primeiro consiste na conceituação, problematização e diferenciação da lógica da mídia e das lógicas da midiatização no contexto das sociedades dos meios e midiatizada, bem como dos regimes de interação e sentido. 0 segundo apresenta e caracteriza cinco casos empíricos à luz dos regimes de interação e sentido, quais sejam: funcionalidades do aplicativo de relacionamento Tinder, tomando como base o regime da programação; comercial da marca Guaraná Antarctica, patrocinadora da Seleção Brasileira Feminina de Futebol em 2019, considerando o regime da manipulação; manifestações de rua no dia do assassinato da vereadora do Rio de Janeiro Marielle Franco, em 2018, segundo a perspectiva do regime do ajustamento; participação do deputado Eduardo Bolsonaro no programa Mega Senha, exibido pela RedeTV, em 2019, conforme o regime do acidente; e o caso do goleiro Sidão, ocorrido em 2019, que articula os quatro regimes. Nas considerações finais refletimos acerca dos resultados da análise dos cinco casos e suas contribuições para o avanço interpretativo das interações midiatizadas à luz dos referenciais teóricos adotados neste artigo.

\section{Arquitetura conceitual: midiatização e interação}

A arquitetura conceitual do artigo se baseia em duas perspectivas de estudo sobre a midiatização, articulando-as com os regimes de interação e sentido (LANDOWSKI, 2014). Em primeiro lugar, são abordadas as perspectivas sobre a midiatização.

\subsection{Perspectivas sobre midiatização}

Segundo Fausto Neto (2008), a primeira percebe o fenômeno da midiatização atrelado à lógica dos meios que se espraia tanto nas práticas comunicacionais das instituições quanto nos diversos campos sociais (política, cultura, religião, entre outros). Daí o enfoque predominante nas instituições de mídia e na lógica do seu funcionamento e padrões estabelecidos em detrimento de outras lógicas criadas e/ou acionadas por diversos segmentos da sociedade, a partir dos usos sociais que fazem dos meios, recursos e aparatos de comunicação.

Pela segunda perspectiva, ainda de acordo com Fausto Neto (2008), a midiatização é compreendida como processo a longo prazo, construído social e historicamente, pois não se 
restringe ao mercado e às indústrias midiáticas, muito menos se instaura a partir do advento das redes sociais online. Assim, variados setores da sociedade também participam do processo de construção da midiatização e de suas lógicas.

Assim, enquanto as lógicas midiáticas são derivadas de padrões empresariais e profissionais, bem como de um perfil massivo de público, instituídas em uma sociedade dos meios ou midiática, as lógicas da midiatização se configuram por múltiplas formas de interação que se tornam processos interacionais de referência no contexto da sociedade em vias de midiatização.

É importante ressaltar que as lógicas da mídia estão diretamente relacionadas com as características da sociedade dos meios, atribuindo ao campo midiático funções regulatórias, organizadoras e mediadoras do funcionamento dos campos sociais. Já as lógicas da midiatização dizem respeito à sociedade em midiatização, em que o campo das mídias perde tais funções, transformando-se em nova ambiência engendradora no modo de ser da sociedade e nos seus processos interacionais. Nesse contexto, produtores e consumidores estão em uma mesma realidade de fluxos e em condições de produzir conteúdos, interagir e se reconhecer, ao mesmo tempo. Mattos, Mendes e Salgado (2021, no prelo) relacionam os regimes de interação e sentido com essas duas noções de midiatização. Antes, porém, de apresentar a correlação entre elas, serão caracterizados os regimes de interação e sentido.

\subsection{Regimes de interação e sentido}

Os regimes de interação e sentido foram concebidos no bojo da sociossemiótica, um dos desdobramentos atuais da semiótica de A. J. Greimas. 0 principal expoente é Eric Landowski (2014), que foi paulatinamente construindo uma semiótica do social a partir de uma narrativização das situações, da política, do direito, da mídia etc. Em Interações Arriscadas, Landowski (2014) apresenta seu modelo teórico interacional. Para o autor, o sentido emana da interação. É a partir da presença do outro e da interação com o outro (pessoa ou coisa) que o sentido se constrói. Tributária em parte da semiótica standard, a proposta de Landowski complementa a semiótica de Greimas e faz com que aumentem, de forma exponencial, as possibilidades de aplicação da teoria narrativa. Trata-se de uma teoria da interação, que considera o entrelaçamento do sentido e do risco e a articulação do sensível com o inteligível. 
São quatro os regimes de interação e sentido: programação, manipulação, ajustamento e acidente. Juntos, os regimes compõem uma sintaxe geral da interação, quer dizer, correlacionam-se entre si, seja por contrariedade, contraditoriedade ou implicação. Tal modelo comporta os mais diversos tipos de interação, seja entre humanos e humanos, humanos e coisas e coisas e coisas. Cada regime é, ao mesmo tempo, de interação, de sentido e de risco (LANDOWSKI, 2014).

0 regime de programação se baseia no princípio da regularidade e implica interações de natureza causal e rotineiras. A programação dá-se em termos de interobjetividade e de exterioridade: construir ou destruir casas, congelar ou descongelar alimentos etc. Em termos modais, caracteriza-se por um fazer-advir. Na programação, o regime de risco é o da segurança e o de sentido é o do insignificante, isto é, as interações por programação possuem um risco baixíssimo, assim como são menos afeitas à produção de sentido, pois o sentido delas é desgastado pelo uso cotidiano.

Diferentemente da programação, o regime de manipulação se estabelece em termos de intersubjetividade e de interioridade. A forma de interação desse regime se dá pela persuasão. Para isso, é preciso adentrar o ser do outro e apresentar-lhe razões para que faça o que dele se espera. Em termos modais, a manipulação traduz-se por um fazer-querer. Trata-se de empreender estratégias para fazer com que o outro faça, quer dizer, de delegar a outrem um fazer. Nesse regime, os interactantes reconhecem-se como sujeitos de fato e de direito por serem dotados de competência modal: querem, podem, devem, sabem, creem (ou não) sobre si e sobre o outro. Por isso, o risco na manipulação é relativamente maior do que na programação: risco limitado e o regime de sentido é o ter significação. Tanto a programação quanto a manipulação são regimes de interação que se baseiam na lógica da junção (LANDOWSKI, 2004) - quando o que está em jogo entre os sujeitos é a circulação de objetos-valor.

0 regime do ajustamento tem como fundamento a sensibilidade. Os interactantes não necessariamente perdem a competência modal, mas o que os guia é a "competência estésica" (LANDOWSKI, 2014, p. 50), isto é, a competência de sentir dos sujeitos. Nesse regime, nenhuma regra é dada a priori. As regras da interação, ao contrário, emergem, pouco a pouco, na e pela interação. É pela relação de copresença sensível entre os interactantes que o sentido se constrói. A forma de interação entre os sujeitos no regime do ajustamento é o contágio (LANDOWSKI, 2004). 
O regime do acidente (ou assentimento) se baseia na lógica da união e na aleatoriedade e comporta eventos imprevistos: desastres naturais, ciclones, avalanches, entre outros. Não há nenhum actante sensível, bom ou mau, responsável por tais acontecimentos ruins - ou bons, como, por exemplo, ganhar na loteria. 0 que permite a existência desses eventos é a pura aleatoriedade, fato que faz com que Landowski (2014, p. 79) conceba o conceito actante joker, aquele que narrativamente faz-ser o acidente. Modalmente, corresponde a um fazer sobrevir, isto é, acontecer de forma abrupta e inesperada. 0 regime de sentido do acidente é o da insensatez. 0 sujeito abalado pelo evento que sobrevém vê-se, momentaneamente, incapaz de produzir sentido, considerando a força e o impacto do evento, que o deixa sem palavras. 0 regime de risco, nesse caso, é o risco puro.

A seguir, o Quadro 1 apresenta graficamente, em forma de elipse, os regimes mencionados. Um regime pode passar a outro por contradição ou por implicação, segundo a ordem das setas:

Quadro 1 - Regimes de interação e sentido

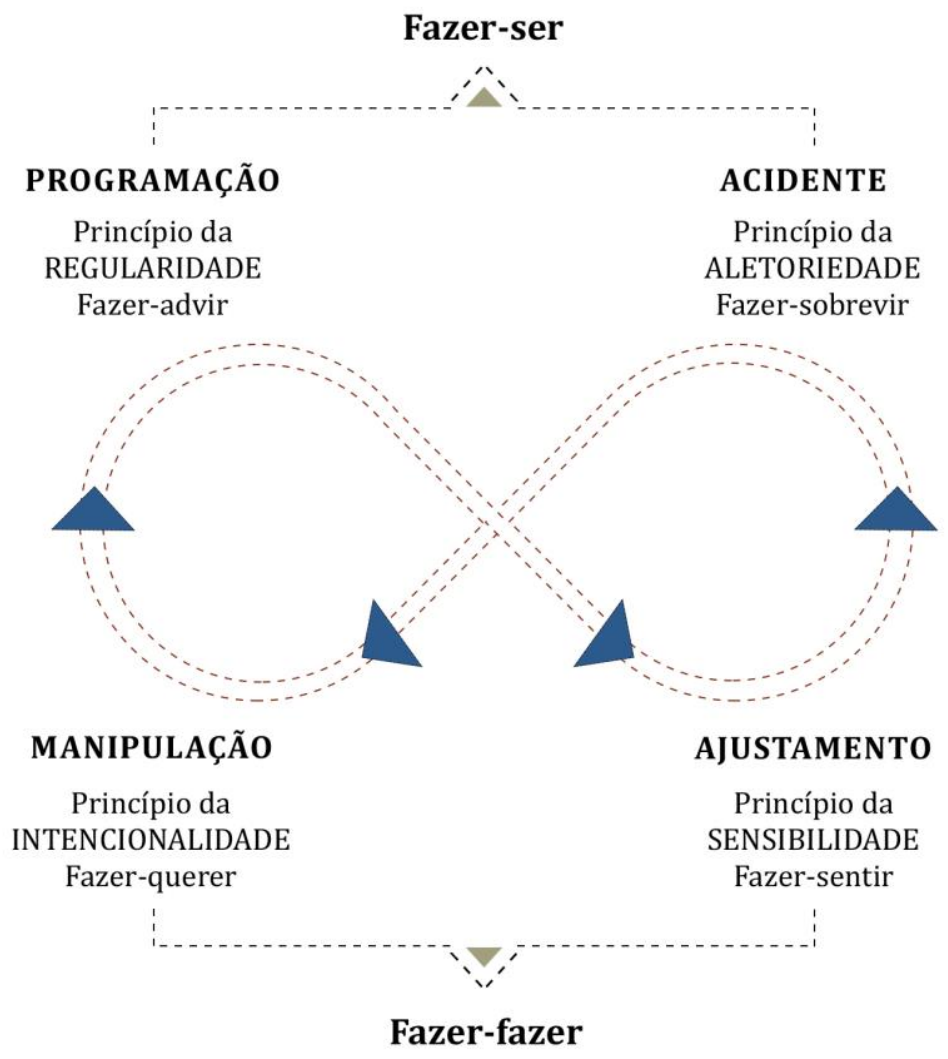

Fonte: Adaptado de Landowski (2014, p. 80). 


\subsection{Convergências entre os regimes de interação e as lógicas da mídia e da midiatização}

A partir dos cinco casos empíricos analisados na próxima seção é possível identificar, com base em Mattos, Mendes e Salgado (2021, no prelo), possíveis convergências entre os regimes de interação e sentido, além de ambas noções sobre midiatização e suas diferentes lógicas.

Os regimes da programação e da manipulação se aproximam de alguns traços da sociedade dos meios e do seu modus operandi, conformando as práticas, as experiências e as interações sociais, seja pela regulação dos sujeitos e das instituições ou pela manipulação, que confere certa racionalidade ao processo de produção e organização do sentido. No que tange, especialmente, às lógicas tecnológicas, Braga (2015) salienta que elas definem, em grande proporção, as práticas interativas e mesmo os objetivos das ações dos sujeitos implicados nos processos de interação. Entretanto, o autor chama atenção para o fato de o âmbito da tecnologia se configurar como terreno movente tanto na sua diversidade quanto na rápida dinâmica de sua invenção, ajustando-se muitas vezes aos valores dos usuários que as acionam, transformando-se pelo seu uso diversificado.

O regime do ajustamento, por sua vez, identifica-se com as dinâmicas processuais dos sujeitos individuais e sociais inseridos no contexto da midiatização, visto reconhecer a ocorrência de zonas de afetação ou zonas de contato (FAUSTO NETO, 2010) entre os sujeitos da interação, o campo midiático e os demais campos sociais, ou seja, tais zonas proporcionam novas modalidades de vínculos e diálogos entre eles. Nesse ambiente midiatizado, tanto os meios massivos, as redes sociais online quanto os espaços públicos se contaminam mutuamente, interdeterminam-se, como também são afetadas por diversas práticas sociais no âmago de seu próprio funcionamento. Nessa ótica, a midiatização transcende os aparatos técnico-midiáticos em si, e ficam turvas as fronteiras entre público e autor, criador e consumidor, especialistas e amador (FAUSTO NETO, 2010). Ademais, os espaços e dinâmicas interacionais não dependem, direta, indireta ou parcialmente do aparato institucional do campo midiático, uma vez que os sujeitos em interação podem criar e acionar seus próprios recursos, linguagens e lógicas. Assim, estão aptos a produzirem circuitos de comunicação mistos - ora difusos, presenciais ou personalizados -, transformando-se em coprodutores de atividades discursivas midiatizadas (FAUSTO NETO, 2010; BRAGA, 2015). 
No regime do acidente, a prevalência da lógica da midiatização se justifica em face da própria volatilidade dos outros processos interacionais em que os direcionamentos não estão dados a priori. Por isso a ocorrência do acidente à medida que a sociedade midiatizada e suas lógicas de funcionamento são mutantes, indeterminadas, inesperadas e variadas, alterando substancialmente as dinâmicas de interação da sociedade dos meios assentada em padrões predeterminados e lineares. Desse modo, as práticas de interação se afastam das noções de equilíbrio e de previsibilidade. Conforme Fausto Neto (2010, p. 92) “[...] significa que são processos que se desdobram, abrem-se em bifurcações, operam através de acoplamentos de operações enunciativas, gerando novas zonas de sentido". Em vista disso, não podemos esquecer que esse regime também pode ocorrer na sociedade dos meios, operando na lógica da mídia, como abordaremos adiante. As correlações entre os regimes de interação e sentido e as perspectivas da midiatização estão representadas no Quadro 2, a seguir:

Quadro 2 - Relação entre regimes de interação e sentido e perspectivas sobre a midiatização

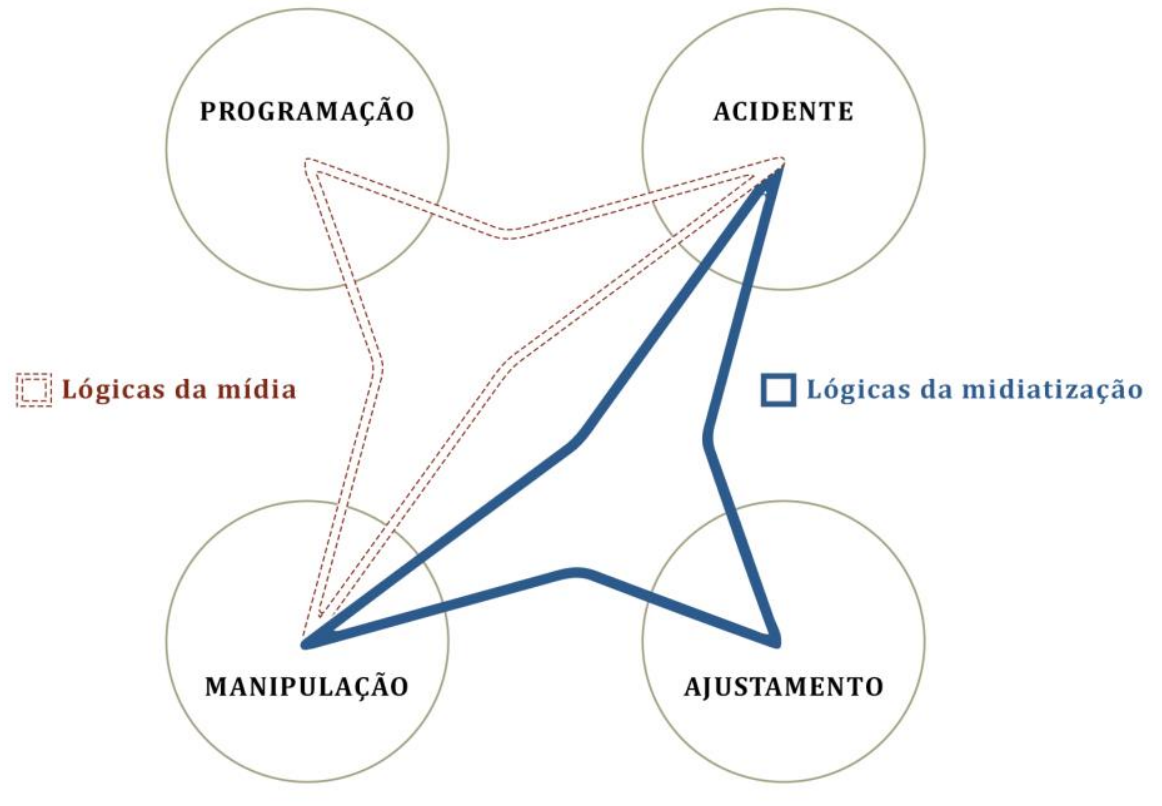

Fonte: Mattos, Mendes e Salgado (2021, no prelo)

Para se evitar uma leitura mecanicista e unilateral dos quatro regimes de interação e sentido, bem como das perspectivas de midiatização e suas lógicas, é importante atentar para o fato de que muito além de uma taxonomia das interações, Landowski (2008) considera que os quatro regimes constituem-se como uma rede de configurações 
interconectadas. Entre eles podem ocorrer bruscas mudanças ou passagens gradativas, superposições ou inclusões de uma grande variedade de interações. Para o autor, os processos interacionais, além de seus aspectos funcionais, podem gerar múltiplos espaços e formas de interação, assim como efeitos de sentido emergentes, contingentes que, se não totalmente imprevisíveis, ao menos processos que ocorrem em situação. Assim, “[...] está previsível que nunca encontraremos, no plano empírico, casos que correspondem estritamente - pura e exclusivamente - a uma dessas definições [tipos de regime de interação] e nada à outra." (LANDOWSKI, 2016, p. 213).

Em síntese, tanto os regimes de interação e sentido podem alterar-se de forma repentina ou lenta e processualmente ao transmutar de um regime a outro, quanto o processo de midiatização pode apresentar lacunas e incompletudes. Dessa forma, há a possibilidade de coexistir, em um mesmo espaço social, traços da sociedade dos meios e da sociedade em midiatização, entrelaçando suas lógicas e as perspectivas analíticas. Braga (2006) corrobora esse argumento ao afirmar que se é verdade que o processo de midiatização se encontra em aceleração, não podemos afirmar que sua predominância seja abrangente, tendo em vista a incompletude estrutural de diversos processos de ordem social, cultural, tecnológica, econômica, entre outros.

\section{Análises de casos empíricos à luz dos regimes de interação e sentido e das perspectivas de midiatização e suas lógicas}

Tendo sido delineados a proposta do artigo, a arquitetura conceitual e os critérios de seleção e parâmetros de análise de cinco casos empíricos, a seguir, são apresentados os estudos de caso de interações midiáticas e midiatizadas, considerando os regime da programação, da manipulação, do ajustamento, do acidente e um caso que apresenta diversas passagens, transposições e sobreposições entre os quatro regimes de interação e sentido.

Os casos empíricos foram selecionados a partir dos seguintes critérios:

a) prevalência de um regime sobre os demais regimes, quando visto sob um determinado ponto de vista ou por um determinado aspecto, com exceção do último caso que obedeceu a critério distinto;

b) coexistência dos quatro regimes de interação e sentido em um único caso, que foi analisado sob diversos e distintos aspectos (técnicos, estéticos, simbólicos, 
subjetivos e intersubjetivos, entre outros), revelando a característica híbrida dos regimes propostos por Landowski (2014);

c) presença das características da sociedade dos meios (lógica midiática) em dois regimes interacionais e de sentido investigados - programação e manipulação -, analisados sob um determinado aspecto, o primeiro do ponto de vista da funcionalidade do aparato técnico-midiático e o segundo do ponto de vista narrativo;

d) presença das características da sociedade em midiatização e de suas lógicas processuais nos casos que se identificam com os regimes do ajustamento e do acidente.

\subsection{A programação no Tinder}

Aplicativos de relacionamento são sintoma dos novos modos de se relacionar amorosa e/ou sexualmente na sociedade contemporânea. 0 Tinder pode ser considerado o caso mais exemplar: é o aplicativo de relacionamento mais baixado no mundo ${ }^{1}$, cujas funcionalidades condicionam a interação entre aplicativo e usuário por meio de processos baseados no princípio da regularidade, que subjaz ao regime da programação. 0 aplicativo se destina a fazer com que pessoas se conheçam, seja para encontrar um par disposto a relação sexual ocasional ou alguém que procure namoro e até casamento (há, ainda, casos menos frequentes de usuários que utilizam o aplicativo com a finalidade de fazer amigos).

A principal regularidade do aplicativo é que, nele, todos procuram e são procurados por sua pré-disposição a se encontrarem. Os usuários assumem o papel temático de sujeito solteiro que representa a disponibilidade ao encontro mediante a sua função de procurar alguém tão disponível quanto ele mesmo. Tal característica não se modifica dentro da plataforma. Portanto, há o princípio da regularidade instaurado nessas interações nas quais a função realizada permanece programada.

Outra regularidade presente no aplicativo diz respeito à forma como um usuário indica se tem ou não interesse nos outros usuários que vão surgindo, como uma incessante sobreposição de cartas virtuais, cada uma com, geralmente, a fotografia do outro usuário. Se houver interesse, o usuário dá um like, isto é, toca o botão verde com o ícone de coração ou desliza o dedo sobre a tela do smartphone para a direita. Caso contrário, quando não houver

${ }^{1}$ Segundo a revista Forbes. Disponível em: encurtador.com.br/hlruP. Acesso em: 19 jul. 2019. 
interesse, toca o botão com o ícone com X vermelho ou desliza o dedo sobre a tela para a esquerda (Figura 1).

Figura 1 - Botão de dislike e botão de like no aplicativo de relacionamento Tinder

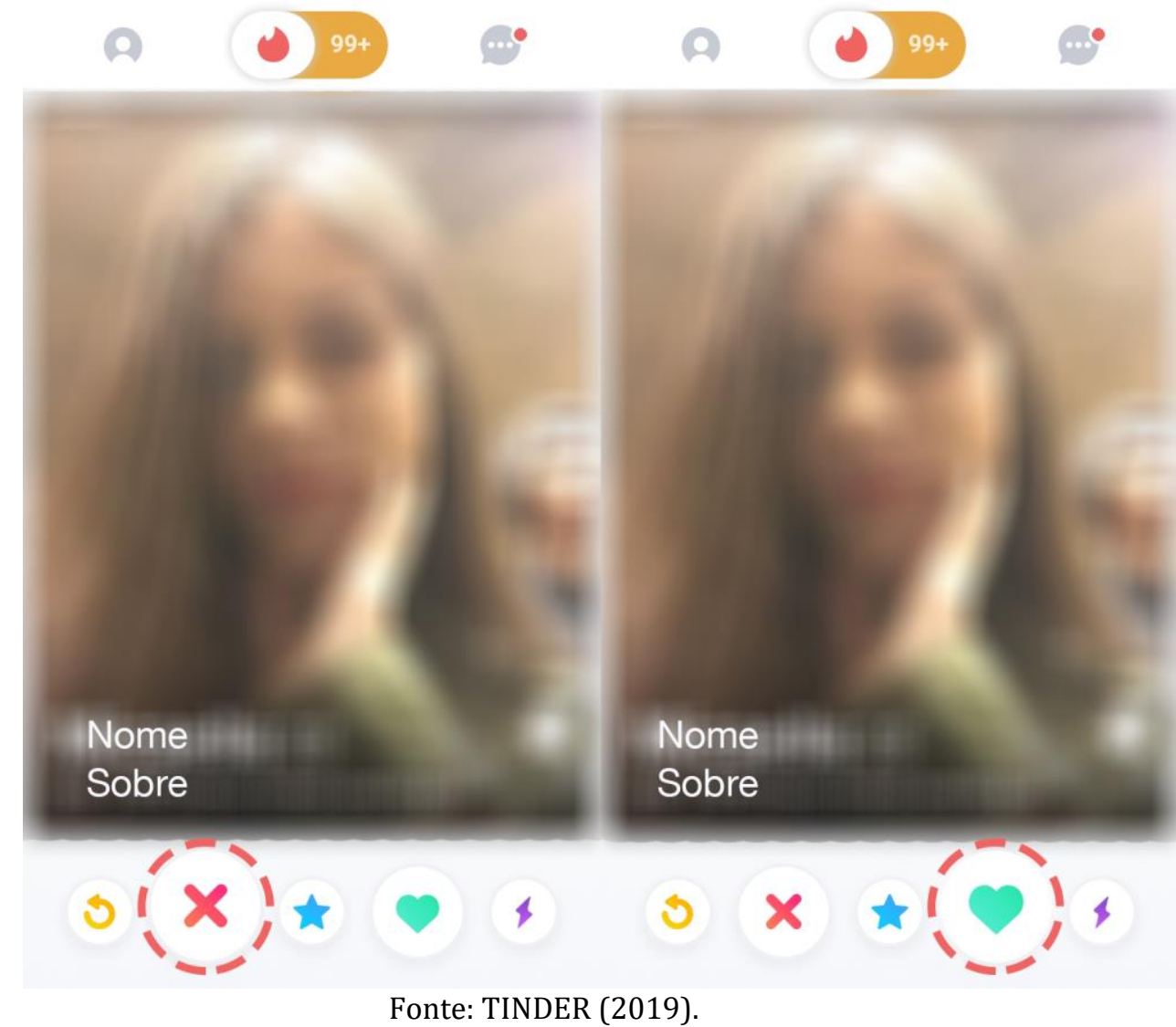

Se ambos apertam o botão like, configura-se um match, ou seja, a correspondência recíproca de likes entre dois usuários do aplicativo (Figura 2). 0 match, em termos semióticos, é a figurativização da relação de conjunção do nível narrativo dos dois interactantes. A partir do match, uma tela de conversação, o chat, é aberta para que os dois usuários possam trocar mensagens na plataforma. 
Figura 2 - Tela do match do aplicativo de relacionamento Tinder

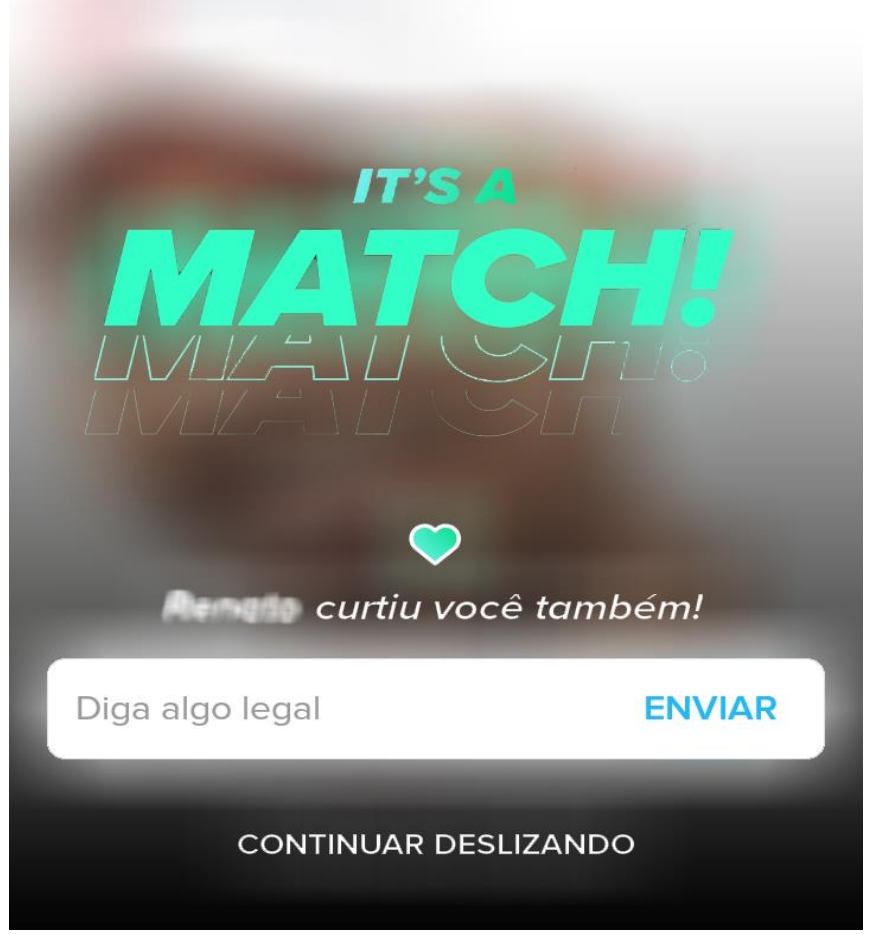

Fonte: TINDER (2019).

O algoritmo do aplicativo também possibilita ao usuário procurar e localizar o posicionamento geográfico de outros. Assim, é possível buscar perfis dentro do limite de raio escolhido. Os usuários são conectados uns aos outros pela posição geográfica e pelas preferências particulares de likes e matchs dados anteriormente e analisados pelo algoritmo, localizados na base de dados do software. As interações são programadas previamente, por meio dos recursos de configurações e edição de informações disponíveis, para regularizar a forma como os usuários interagem uns com os outros. Tais recursos possibilitam delimitar a idade, o gênero, o limite de distância e quais e quantas informações de si se deseja descrever (Figura 3). 
Figura 3 - Recursos de configurações e edição de informações pessoais no aplicativo de relacionamento Tinder

\section{Mostrar-me \\ Homens}

Mulheres

\section{Distância máxima}
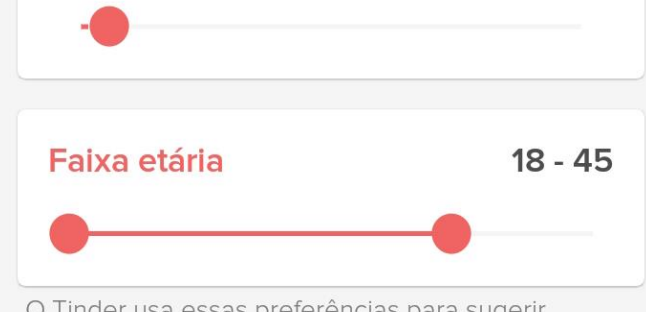

O Tinder usa essas preferências para sugerir Matches. Algumas sugestões podem não estar dentro dos seus parâmetros ideais.

Mostrar-me no Tinder

Você não aparecerá na coleção de cartões, mas ainda poderá enviar mensagens para os Matches já existentes.
Sobre

\section{Cargo}

Adicionar cargo

\section{Empresa}

Adicionar empresa

Escolaridade

Adicionar

Morando em

\section{Adicionar cidade}

Sexo

Homem

Mulher

Fonte: TINDER (2019).

As funcionalidades do Tinder descritas implicam a relação entre usuários e aplicativo. No entanto, quem se utiliza do software tem uma intencionalidade clara: procurar/encontrar e ser procurado/ser encontrado por outro sujeito que julgar ser interessante e desejável. Para isso, busca construir uma imagem favorável de si, seja colocando as fotos de si que acredita serem as melhores ou fazendo uma descrição que tem por objetivo tornar-se interessante para o outro. Ainda que essas ações pautem-se pelo princípio da intencionalidade, na prática, as formas de se apresentar como um sujeito interessante também obedecem ao princípio da regularidade, pois se repetem. E, por se repetirem tanto, tendem a dessemantizarem-se no limite e tornarem-se desgastadas em função do uso mecanizado. 0 outro passa, muitas vezes, a ser apenas uma imagem cujo like, dislike ou match é só mais um, num fluxo sem fim de novos perfis que se dão a ver. 
Assim, por um lado, os aspectos relacionados às funcionalidades técnicas do Tinder fazem com que seja possível inseri-lo no regime da programação, como também na lógica da sociedade dos meios. Isso porque o aplicativo é determinado pela regulação das formas de interação entre os sujeitos, além de agenciar os primeiros contatos e a sua continuidade, a localização geográfica dos usuários até a rejeição ou a aceitação do perfil de outros. Por outro lado, a programação é apenas o primeiro regime que possibilita o surgimento de outros regimes interacionais no e em torno do aplicativo. A partir desse regime, desenvolvese, por exemplo, o regime da manipulação: fazer-se interessante para o outro, ou seja, a conquista, o flerte. $\mathrm{Ou}$, ainda, o regime do acidente, pois os perfis vão aparecendo para o usuário seguindo critérios pré-definidos (idade, gênero etc.), mas também obedecem ao princípio da aleatoriedade, pois não se sabe quem dentro desse universo aparecerá para o usuário. Assim, para além de aspectos tecnológicos, aplicativos de relacionamento dão origem a outras práticas de relacionamento amoroso e/ou sexual na contemporaneidade, haja vista que prescinde inclusive da mediação dos meios, a exemplo de antigos programas de TV como Em nome do amor e Namoro na TV, exibidos pelo SBT nas décadas de 1990 e 2000. Portanto, se no que diz respeito às funcionalidades, o Tinder se aproxima da sociedade dos meios, as novas práticas interacionais que ele instaura o inserem na perspectiva da sociedade em midiatização.

\subsection{A manipulação na campanha do Guaraná Antarctica e o futebol feminino}

Em 2019, a Rede Globo exibiu, pela primeira vez na história, a Copa do Mundo de Futebol Feminino. Esse fato atesta que o futebol profissional jogado por mulheres está a anos luz aquém do futebol masculino, seja em termos de visibilidade, patrocínio, engajamento etc. Vários clubes nacionais de ponta ainda não possuem times de futebol estruturados e, mesmo que a principal jogadora de futebol feminino do mundo seja a brasileira Marta, premiada seis vezes de Melhor Jogadora do Mundo pela FIFA, recordista de todos os tempos em prêmios entre mulheres e homens, as oportunidades no mercado ainda são restritas para as atletas, o que propicia ações de busca por lugares de visibilidade.

Às vésperas do campeonato, a marca Guaraná Antarctica, patrocinadora da Seleção Brasileira Feminina de Futebol, lançou um comercial com as jogadoras Andressinha, Cristiane e Fabi Simões, convocando outras marcas a também patrocinarem o futebol 
feminino (Figura 4) ${ }^{2}$. A primeira parte do comercial evidencia a quantidade de marcas que contaram com os jogadores da Seleção Brasileira Masculina em 2018, ano da Copa do Mundo de Futebol Masculino. 0 anúncio diz: “[...] e este ano quase nenhum [comercial] com as jogadoras", demonstrando o cenário discrepante de investimento e visibilidade entre futebol feminino e masculino. Ao longo do vídeo, o comercial ironiza a capacidade de as jogadoras realizarem tarefas desempenhadas por jogadores homens em outros comerciais: "Afinal, será que a Fabi Simões não é boa o suficiente para colocar Guaraná em um copo cheio de gelo?"; "Será que a Andressinha não consegue tomar um gole de Guaraná em câmera lenta e fazer 'Ahhh' depois?”; “E a Cristiane, vai dizer que uma das maiores artilheiras de todas as seleções não consegue falar o slogan da nossa marca?". Desse modo, o comercial ironiza e explicita o subentendido contido nos comerciais das demais marcas, segundo o qual, para as outras marcas, as mulheres são menos capazes que os homens de exercer tais funções nos anúncios publicitários e, por dedução, no campo de futebol e na vida. Com isso, a marca Guaraná Antarctica posiciona-se como pró-feminista.

Figura 4 - Frame do comercial da Guaraná Antarctica com as jogadoras da Seleção Brasileira de Futebol

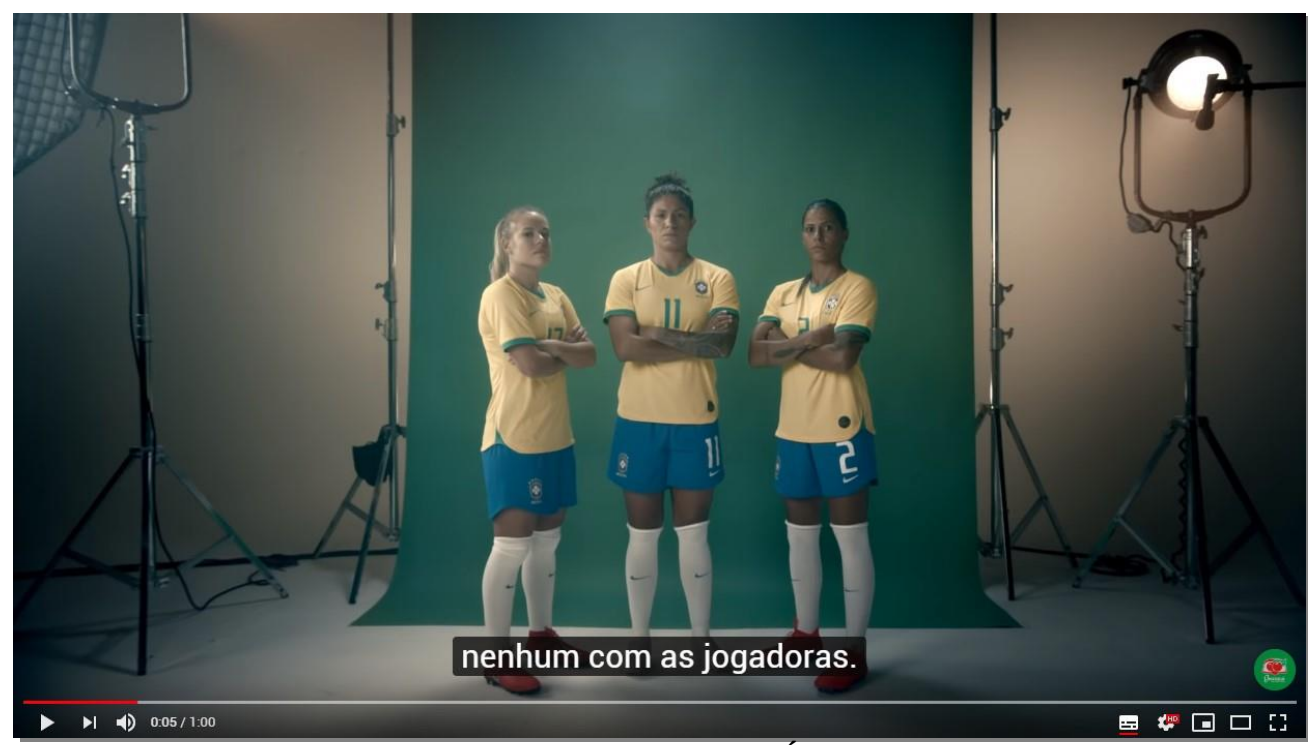

Fonte: Adaptado de YouTube (GUARANÁ ANTARCTICA, 2019).

O comercial possibilita exemplificar o regime da manipulação, ao proceder a uma intrincada rede manipulatória. Inicialmente, a marca Guaraná Antarctica apresenta-se como patrocinadora da Seleção Brasileira de Futebol Feminino. Em termos narrativos, apresenta-

2 Disponível em: encurtador.com.br/fuCG2. Acesso em: 17 jun. 2019. 
se como um sujeito que faz-ser. Com isso, constrói uma imagem de marca inclusiva e apoiadora de um esporte cuja modalidade feminina, não obstante a tradição do futebol masculino no Brasil, tem pouca importância, visibilidade e, logo, pouco patrocínio das outras marcas.

A marca Guaraná Antarctica (destinador) convoca outras marcas de variados segmentos (destinatário) a patrocinar o futebol feminino. 0 destinador manipula por provocação, quando afirma (GUARANÁ ANTARCTICA, 2019, n.p): “uma vergonha, não?” (não haver oportunidades comerciais para o futebol feminino), sugerindo que as outras marcas não são inclusivas e pró-feministas. A empresa conclui fazendo o convite: "junte-se a Guaraná nesse movimento. Afinal, é coisa nossa ter orgulho da seleção" (GUARANÁ ANTARCTICA, 2019, n.p), questionando, ainda, o patriotismo das demais marcas, que, supostamente, deveriam ter feito o que delas se esperava (ter patrocinado a seleção feminina) e não fez, isto é, ao questionar o patriotismo das outras marcas, manipula por provocação.

Ao lado de uma manipulação por provocação para com as outras marcas, a marca Guaraná manipula ${ }^{3}$ os consumidores (enunciatário) por sedução/lisonja, uma vez que faz dele uma imagem positiva, ou seja, o enunciador parte do princípio de que o brasileiro é patriota e que é um ato de patriotismo "ter orgulho da seleção [feminina]" (GUARANÁ ANTARCTICA, 2019, n.p). Esses dois tipos de manipulação citados “[...] jogam com as conotações, positivas ou negativas, da imagem que o manipulador faz ou pretende fazer daquele que deseja manipular" (LANDOWSKI, 2014, p. 26).

O fazer-fazer da manipulação caracteriza-se, nesse caso, pelo caráter de menor risco e possibilidade de estabelecer contratos entre os sujeitos. Logo, ao buscar estabelecer um contrato por meio da manipulação, ela procura comungar dos mesmos valores e crenças de seus consumidores potenciais. Para as empresas que ali foram convocadas a atuar, são oferecidas condições necessárias para realizar a ação, ou seja, são doadas a elas competências modais.

Assim, a partir da lógica da junção, havia um sujeito de estado (seleção feminina de futebol) em disjunção com o objeto-valor (reconhecimento e patrocínio). A marca Guaraná Antarctica age narrativamente como um sujeito operador que faz-ser, isto é, que patrocina a seleção feminina e, como um sujeito manipulador, faz com que outras marcas façam o

\footnotetext{
3 Vale lembrar que, em semiótica, manipular não possui necessariamente conotação negativa. Diz respeito, tão somente, a fazer crer, fazer querer e, sobretudo, fazer fazer.
} 
mesmo. Várias marcas se mostraram interessadas em patrocinar o futebol feminino, como mostra a reportagem de Meio e Mensagem ${ }^{4}$, demonstrando que a manipulação do Guaraná Antarctica foi bem-sucedida.

Diante do exposto, foi possível verificar que o comercial da marca Guaraná Antártica baseou-se no regime da manipulação, haja vista o contrato estabelecido tanto com outras marcas quanto com os consumidores. Nesse ambiente de comunicação, as lógicas comerciais e publicitárias prevalecem sobre as demais lógicas sociais. Ainda que os consumidores da marca possam se comportar e interagir diante/com esse anúncio de formas variadas, o público é pensado sob a ótica de audiência massiva. E, mesmo considerando o crescente processo de segmentação das campanhas publicitárias na atualidade e de adoção de estratégias de convocação (provocação) utilizadas no anúncio estudado - que se alinham ao marketing de engajamento voltado a construir relações afetivas com os consumidores e com outras marcas do produto -, foi possível identificar a predominância da manipulação em relação aos demais regimes de interação e sentido, bem como das lógicas empresariais/publicitárias.

\subsection{O ajustamento estésico nas manifestações por Marielle Franco}

"Quantos mais vão precisar morrer para que essa guerra acabe?" (FRANCO, 2020). Esta foi a frase publicada no Twitter pela vereadora do Partido Socialismo e Liberdade (PSOL), Marielle Francisco da Silva Nascimento (Marielle Franco), um dia antes de ser executada por milicianos com quatro tiros na cabeça, em 14 de março de 2018, no Rio de Janeiro. Sempre se apresentando como mulher negra, feminista, periférica, lésbica e defensora dos direitos humanos, a parlamentar criticava abertamente a violência policial nas favelas do Rio de Janeiro.

Minutos após o assassinato, uma série de protestos tomou conta das redes sociais no Brasil e no mundo, com pessoas se manifestando por meio das hashtags: \#mariellefrancopresente, \#justiçaparamarielle, \#nãofoiassalto e \#mariellevive. Horas depois, as palavras de ordem produzidas e compartilhadas no Facebook, Twitter e WhatsApp se materializaram na voz de milhares de pessoas que foram às ruas no país exigir justiça contra os mandantes e executores do crime (Figura 5).

${ }^{4}$ Disponível em: encurtador.com.br/sACE4. Acesso em: 17 jun. 2019. 
Figura 5 - Manifestações no Rio de Janeiro após o assassinato de Marielle Franco

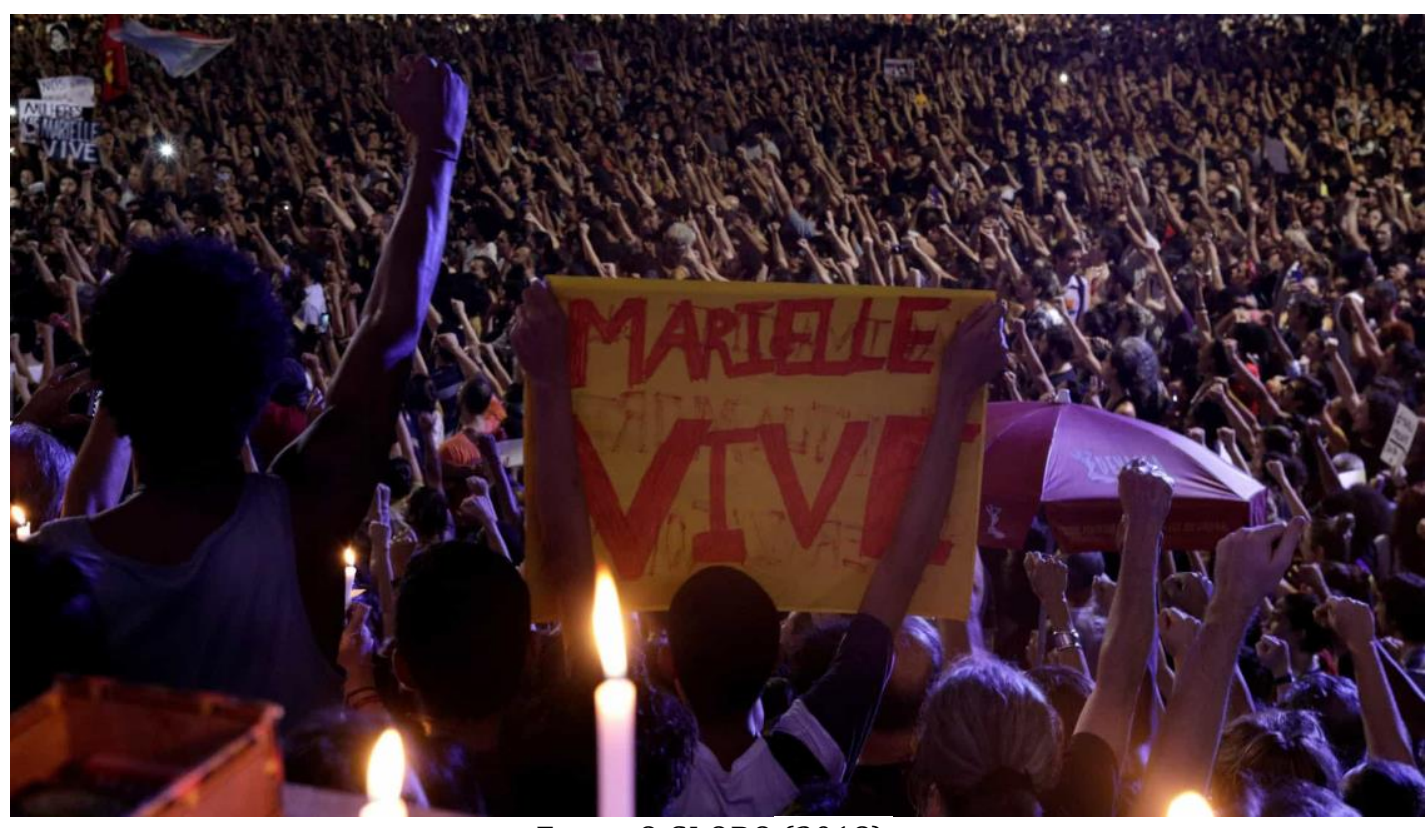

Fonte: O GLOBO (2018).

Além de não fazerem parte do círculo íntimo de Marielle Franco (familiares e amigos), a maioria dos manifestantes dispunha de pouca ou nenhuma informação sobre ela. Isso não os impediu, entretanto, de se sentirem afetados e contagiados por outros sujeitos em copresença sensível. Segundo Landowski (2004, p. 115, tradução nossa), no regime do ajustamento, "[...] a interação contagiosa não implica nenhuma operação de conjunção entre sujeito e objeto" , pois "o contágio opera independente da transmissão de qualquer objetovalor que esteja sobre o plano cognitivo" (LANDOWSKI, 2004, p. 116, tradução nossa)5. Assim, na ocasião, por meio da exposição de sentimentos como compaixão e respeito, indignação e medo, os manifestantes estabeleceram entre si uma interação caracterizada por um fazer sentir.

0 ajustamento estésico, oriundo da sensibilidade perceptiva dos manifestantes, possibilitou-lhes não apenas “[...] sentir as modulações internas que afetam os estados do corpo próprio, mas também interpretar o conjunto dessas soluções de continuidade em termos de sensações diferenciadas que fazem por si mesmas sentido." (LANDOWSKI, 2014, p. 52). Tal experiência evidencia-se no comunicado feito pela Frente de Mulheres do PSOL no dia do crime: "Hoje, nossa esperança se quebra um pouco. Uma mulher, negra, mãe,

\footnotetext{
${ }^{5}$ No original : “[...] [l'] interaction contagieuse [...] ne résulte d'aucune opération de conjonction entre sujet et objet [...]» [parce que] « [...] la contagion opère ici sans la médiation [...] de quelque objet de valeur que ce soit sur le plan cognitif [...]”.
} 
lésbica, defensora da igualdade e nascida e criada na favela da Maré foi derrubada" (OLIVEIRA; GARCIA, 2018, p. 1078). Mediante o assassinato de Marielle Franco, os manifestantes ajustaram-se sensivelmente uns aos outros, em estados patêmicos inúmeros e muitas vezes sem nome. Era, em suma, a estesia que os unia.

As manifestações de protesto contra o assassinato de Marielle Franco representam uma experiência estética e estésica típica da sociedade em midiatização, uma vez que se pauta por outras lógicas e procedimentos, muitos dos quais experimentais e acionados por diversos segmentos sociais. 0 entrelaçamento entre o presencial (manifestação de rua) e o midiatizado (usos e apropriações sociais de diversos dispositivos técnico-midiáticos e extramidiáticos - redes sociais online, faixas, cartazes, músicas, entre outros recursos e estratégias sensíveis) e suas incidências mútuas, produziu um circuito comunicacional agenciado por múltiplos setores e movimentos sociais, extrapolando a lógica da mídia e explorando recursos criativos e inventivos de interação. Daí as expressões tentativas e experimentais utilizadas por Braga (2015) para caracterizar as lógicas da midiatização, uma vez que geram dispositivos interacionais que se espraiam na vida social, neste caso, construindo fortes vínculos afetivos entre os manifestantes, extrapolando para outros sujeitos e coletivos que criam e compartilham imagens, palavras de ordem, hashtags, cantos, entre outros recursos nas redes sociais online, além da veiculação dos protestos pelos meios tradicionais.

\section{4 $\mathrm{O}$ acidente de Eduardo Bolsonaro}

No dia 19/05/2019, o programa Mega Senha, exibido pela RedeTV, teve o deputado federal do PSL-SP, Eduardo Bolsonaro, filho do atual presidente do Brasil, Jair Bolsonaro, como um dos convidados. Transmitido, o jogo consiste em um jogo de palavras no qual dois participantes concorrem a uma premiação em dinheiro. 0 vencedor é aquele participante que consegue, junto com sua dupla, adivinhar o maior número de senhas (palavras que são mostradas aos públicos, mas não ao participante) a partir de dicas que são fornecidas por seu parceiro na competição. Dessa maneira, as senhas são reveladas a partir da associação entre palavras.

Durante sua participação, foi apresentada a Eduardo a palavra-chave livre. A partir disso, ele deveria fornecer dicas que permitissem que sua parceira adivinhasse a palavra secreta. A primeira tentativa do político foi a palavra preso que fez com que a competidora 
A midiatização e suas lógicas: análise de casos à luz dos regimes de interação e sentido

respondesse solto. Sua segunda dica foi cadeia, porém também não obteve sucesso. Por fim, Eduardo Bolsonaro disse Lula, fazendo referência à expressão Lula Livre para que a competidora pudesse associar as palavras Lula e Livre e acertar a senha proposta (Figura 6).

Figura 6 - Eduardo Bolsonaro em participação no programa Mega Senha, da RedeTV

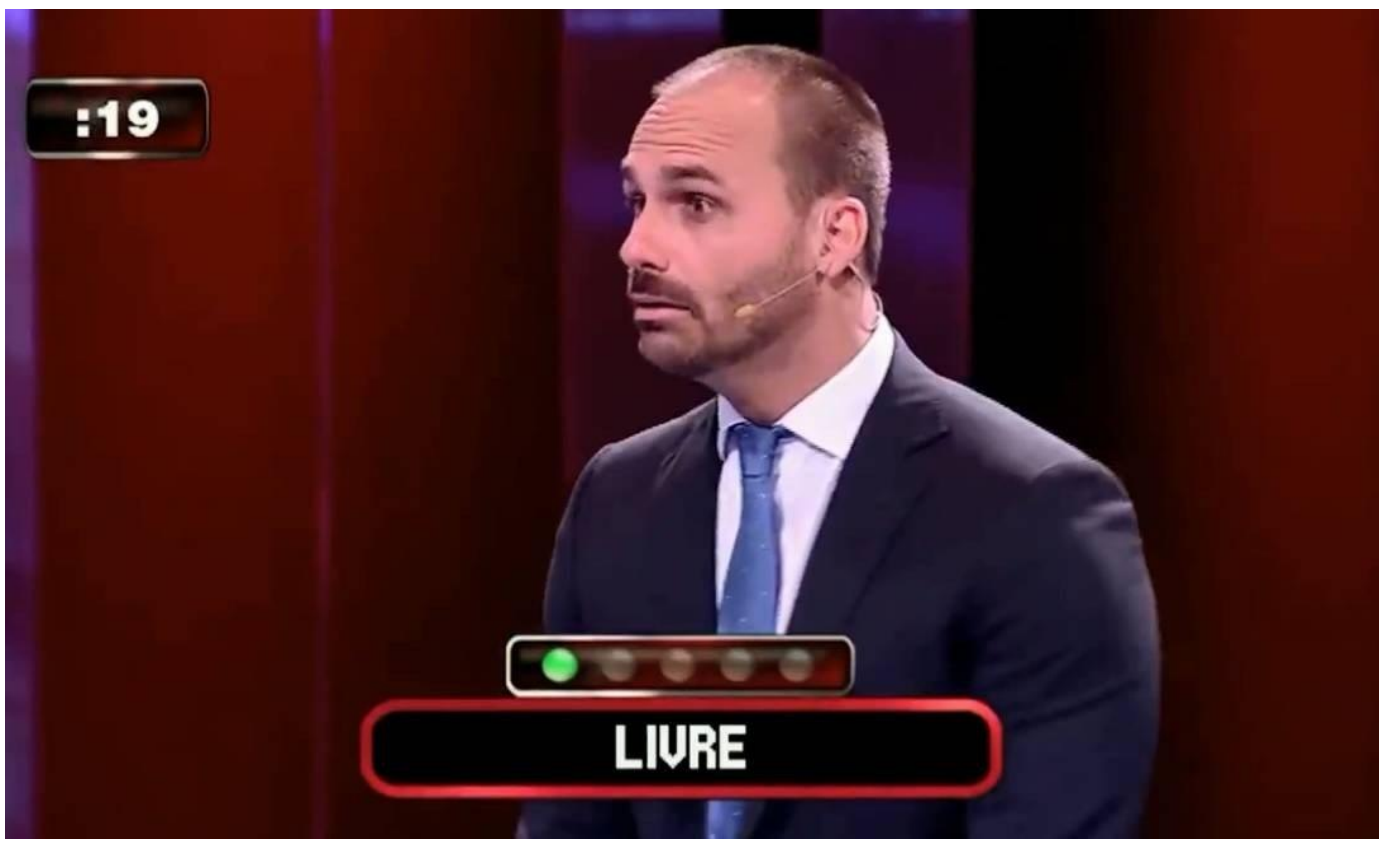

Fonte: O GLOBO (2019).

Desde que o ex-presidente Lula foi preso, em 7/4/2018, Lula Livre é uma expressão que se popularizou a partir da campanha do Comitê Internacional de Solidariedade em Defesa de Luiz Inácio Lula da Silva e da Democracia no Brasil. Lula é membro fundador do Partido dos Trabalhadores (PT), que possui divergências políticas e ideológicas com o partido de Eduardo Bolsonaro (PSL). Devido ao antagonismo político entre os dois partidos, a associação de Eduardo à expressão Lula Livre viralizou nas redes sociais online, conforme (Figura 7). 
Figura 7 - Repercussão no Twitter da participação de Eduardo Bolsonaro no programa Mega Senha, da RedeTV

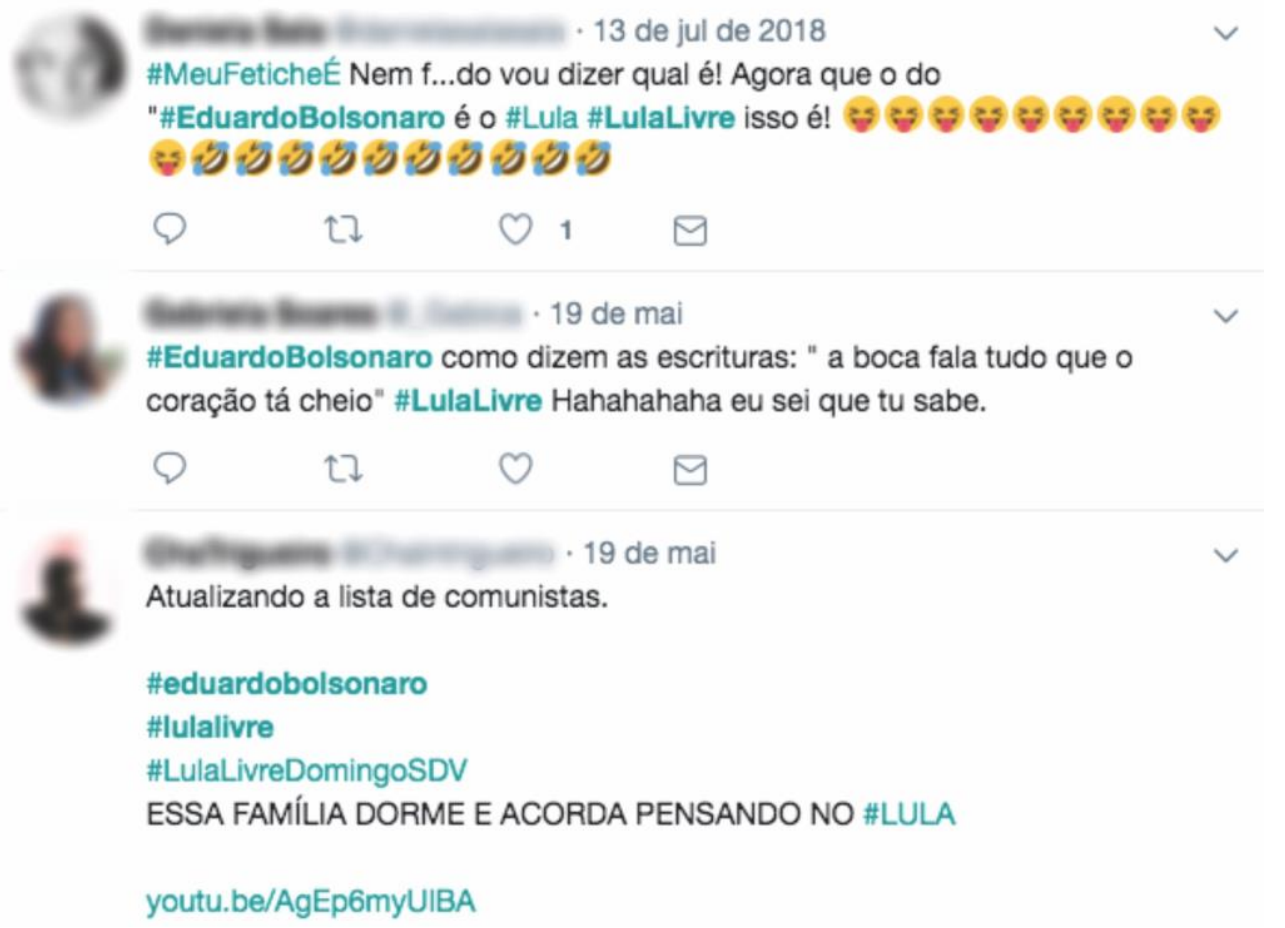

Fonte: TWITTER (2019).

Assim, ao dizer Lula associando o termo à palavra secreta livre, é como se o próprio Eduardo Bolsonaro tivesse enunciado o que jamais teria feito pública e conscientemente: clamar pela liberdade de um dos inimigos políticos de seu pai. De acordo com os regimes de interação propostos por Landowski (2014), o acidente implica uma ruptura, uma descontinuidade. Está associado àquilo que não pode ser previsto e nem evitado, como foi o caso aqui descrito. A escolha da palavra Lula para associar a livre irrompeu como um acidente: disruptivo, inesperado, aleatório. Com efeito, o acidente é definido como "[...] a afirmação do termo negativo da categoria cuja programação representa o termo positivo" (LANDOWSKI, 2014, p. 71). O regime do acidente irrompe numa continuidade - a programação - e aporta um sentido excessivo que, justamente por isso, prescinde, momentaneamente, de significação.

Ainda que possa haver uma regularidade imperceptível em alguns eventos imprevistos, para Landowski (2014, p. 75), “[...] pode-se também [assumir o aleatório] como tal, isto é, admitir que existem de fato fenômenos cuja aparição não é explicável por qualquer regularidade de ordem causal nem por qualquer constante de ordem simbólica". É 
justamente aí que reside a explicação do que ocorreu com o deputado Eduardo Bolsonaro, ao relacionar parte do nome do ex-presidente da República Lula ao termo livre, de forma inesperada e indesejada. Sua expressão de indignação e de surpresa com a própria atitude (Figura 4) é emblemática em relação ao fenômeno do acidente nas interações midiatizadas. Nessa configuração, a lógica do acaso e a lógica da circulação instantânea prevaleceram no cenário da sociedade em vias de midiatização, à medida que esse acontecimento viralizou imediatamente nas redes sociais online e em outros meios de comunicação massivos (Figura 7).

\subsection{O caso Sidão e a articulação entre os quatro regimes de interação e sentido}

No contexto da sociedade em midiatização, o caso do atual goleiro do Vasco da Gama, Sidney Aparecido Ramos da Silva, o Sidão, ganhou repercussão internacional ${ }^{6}$ e viralizou nas redes sociais online. 0 episódio é emblemático para ser discutido nesta última subseção, pois articula e demonstra as passagens e as sobreposições entre os quatro regimes de interação a partir de lógicas da midiatização, considerando os fluxos circulatórios de conteúdo entre diversas plataformas.

Lançado como novidade para o Brasileirão 2019, o Craque do jogo 7 é uma premiação do Globo Esporte que consiste em eleger por votação, feita exclusivamente online, o melhor jogador de cada partida de futebol disputada durante as rodadas do campeonato. Assim, a partir da escolha dos públicos, o programa entrega um troféu, no final do jogo, ao atleta eleito com o melhor desempenho. Desse modo, tal premiação define-se pelo princípio da regularidade: a votação deve ser realizada online; os públicos escolhem o melhor jogador da partida; um troféu é entregue ao final da partida ao escolhido. Existe, portanto, uma programação, uma regularidade de ações desempenhadas a partir de regras determinadas pela premiação. A princípio, nada mais implicativo (foi o melhor jogador, então foi premiado) e, portanto, programático.

\footnotetext{
${ }^{6}$ Repercussão internacional: entrega de troféu a Sidão é destaque em jornal na Europa. Disponível em: encurtador.com.br/hFL46. Acesso em: 13 jul. 2019.

7 Troféu Craque do Jogo é a novidade do Brasileirão 2019. Disponível em: encurtador.com.br/dqBLO. Acesso em: 13 jul. 2019.
} 
Todavia, em 13/05/2019, o resultado da votação não se pautou pela lógica implicativa, mas pela lógica concessiva ${ }^{8}$ (apesar de ter sido o pior jogador, ele foi premiado): o goleiro Sidão foi eleito o melhor jogador pelos internautas, quando, na verdade, figurou entre os piores, por ter sofrido três gols, tendo, com isso, contribuído para a derrota do Vasco. Antes de nos determos no que veio a ser uma interação baseada no regime do acidente, quer dizer, na inesperada escolha de Sidão, é preciso analisar o regime da manipulação que lhe precedeu.

Na esteira desse regime, o destinador Grupo Globo propõe um contrato ao destinatário audiência: votar pela internet no melhor jogador da partida. Entretanto, o destinatário audiência rejeita o contrato proposto pelo destinador Grupo Globo e estabelece um contrato com um outro destinador: o maior canal de entretenimento, futebol e humor do Brasil no YouTube, o Desimpedidos ${ }^{9}$. Na descrição deste canal encontramos sua definição: "onde a zueira não tem limites". O contrato proposto pelo destinador Desimpedidos foi publicado no Twitter (Figura 8).

Figura 8 - Publicação do Desimpedidos em seu perfil no Twitter

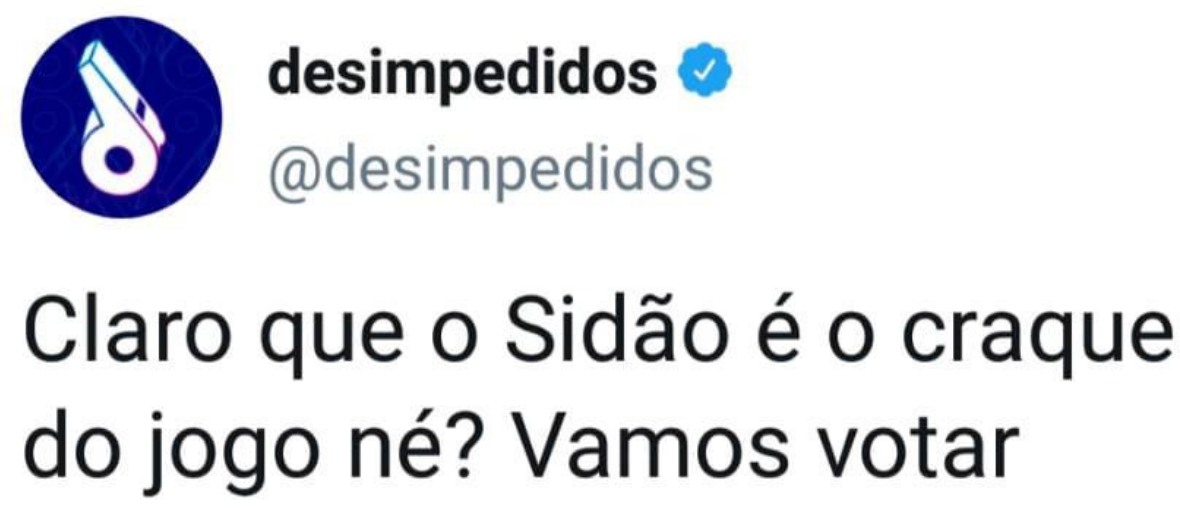

Fonte: LANCE (2019).

Assim, a votação do dia teve suas regras burladas e, em uma espécie de bullying dos internautas engajados pelo Desimpedidos, o goleiro Sidão foi eleito o melhor jogador. A manipulação do Desimpedidos em relação ao destinatário audiência não se deu em bases puramente cognitivas. A zoeira, como eles definem, tem a ver com paixões malevolentes, isto

\footnotetext{
8 Para Zilberberg (2011, p. 242), a lógica concessiva, que está no cerne da noção de acontecimento, refere-se à ideia do "apesar de $\mathrm{x}, \mathrm{y}$ ", ou seja, a concessão fala precisamente daquilo que não se espera, mas que acontece, daquilo que sobrevém, sem que se esteja preparado para tal.

9 Com mais de 7 milhões de inscritos apenas no YouTube e mais de 15 milhões de seguidores em todas redes sociais online em que atuam, o Desimpedidos foi criado em 2013 por Felipe Andreoli, André Barros, Antonio Tabet, Rafael Grostein e o exjogador Kaká. Disponível em: encurtador.com.br/hjDH4. Acesso em: 13 jul. 2019.
} 
é, quando um sujeito quer impingir sofrimento a outro, ainda que seja, supostamente, pela via do humor. Assim, a manipulação entre Desimpedidos e audiência é de índole patêmica, quer dizer, faz querer, mas também faz sentir, seja riso, escárnio, sadismo, entre outros estados de alma.

A Rede Globo optou por entregar o prêmio para Sidão, mesmo estando ciente de que o resultado havia sido, propositalmente, incoerente com o desempenho do jogador. 0 goleiro recebeu a premiação ainda ao final do jogo, com clara expressão de constrangimento, também expressa pela repórter (Figura. 9).

Figura 9 - Momento em que o jogador Sidão recebe a premiação de Craque do Jogo

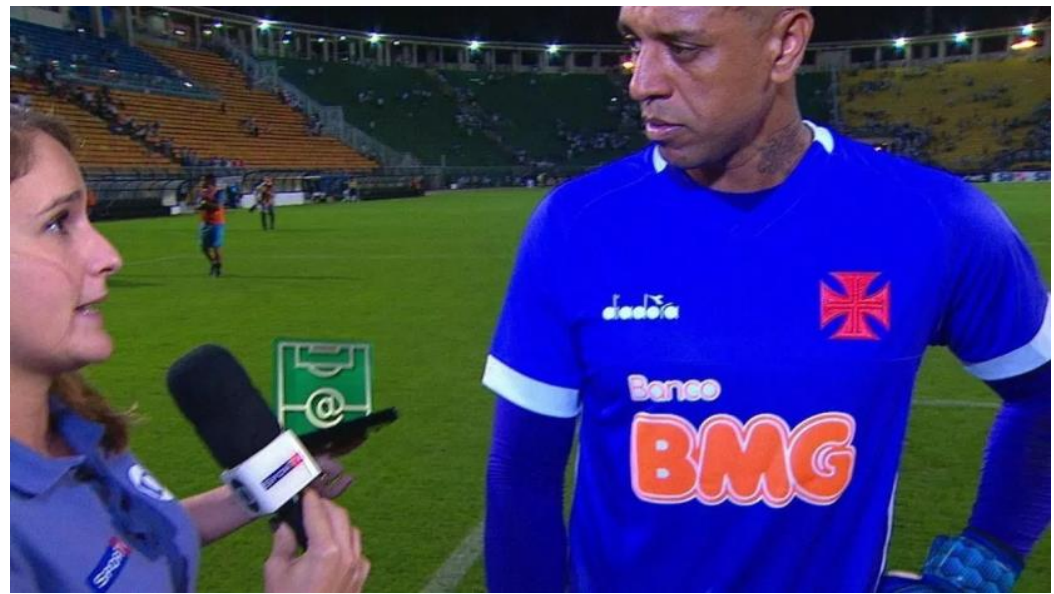

Fonte: AUDIÊNCIA CARIOCA (2019).

Desse modo, a entrega do prêmio, pela perspectiva do jogador Sidão e dos telespectadores que não estavam cientes do contrato estabelecido entre internautas e o canal Desimpedidos, configura-se como uma interação baseada no regime do acidente, uma vez que foi inesperada e calcada no princípio da aleatoriedade. Do ponto de vista do Desimpedidos e dos internautas, vigorava o regime da manipulação, posto que se ancorava no princípio da intencionalidade.

$\mathrm{O}$ caso repercutiu nas redes sociais online e comoveu atletas e jornalistas que se posicionaram contra a postura da Rede Globo e solidários ao jogador. Programas esportivos de grande audiência como Os Donos da Bola (Band), Futebol na Veia (ESPN Brasil) e A Última Palavra (FOX Sports) tiveram partes dedicadas a discutir sobre o caso e evidenciar a postura da Globo ao premiar o jogador, mesmo com a possibilidade de que o resultado da votação fosse vexatório. Delegações esportivas como o Palmeiras e o Santos usaram seus perfis nas redes sociais online para prestar apoio ao esportista, assim como atletas também 
se manifestaram sobre o caso. A repercussão do caso Sidão implica interações baseadas no princípio do ajustamento. Havia uma coletividade de sujeitos, de estesias que sentiam compaixão e faziam-se sentir mutuamente em copresença midiatizada.

Criticado, principalmente nas redes sociais online, o Grupo Globo se posicionou em nota oficial veiculada no site da emissora:

A partir da próxima quarta-feira, quando começam as oitavas de final da Copa do Brasil, a votação do Craque do Jogo terá um novo formato. 0 público seguirá tendo voz através das enquetes na página globoesporte.com/craque, agora em companhia dos comentaristas da TV Globo, que terão direito a voto [...].10

Observamos, pelo comunicado da Globo, que a emergência de interações que não se basearam no regime da programação, como seria esperado pela emissora (acidente do ponto de vista de uns, manipulação do ponto de vista de outros) ensejou uma reprogramação: os públicos podem votar, mas o resultado é referendado por seus comentaristas esportivos. No quadro fixo do programa Fantástico, que mostra os gols da rodada do Brasileirão, também houve uma tentativa de esclarecer os fatos e falar sobre as mudanças no formato da premiação. Além das pautas direcionadas a emissora, o canal Desimpedidos foi criticado e perdeu credibilidade e seguidores pelas ações movidas nas redes sociais online, por promover o bullying com Sidão, por meio de uma espécie de boicote à premiação do Globo Esporte.

O caso Sidão é exemplar por explicitar as interações que se estabelecem a partir de todos os regimes de interação e sentido apresentados ao longo deste artigo: (i) programação; (ii) manipulação; (iii) acidente; (iv) ajustamento; (v) (re)programação. A sequência como foram aqui sintagmaticamente dispostos não representa uma passagem unilateral e sequencial, ao contrário, os regimes descritos se sobrepõem, mesclam-se e condicionam uns aos outros.

\section{Considerações finais}

A articulação entre os aportes teóricos do artigo e os cinco estudos empíricos desenvolvidos nos levaram a compreender que as lógicas da midiatização são muito mais

\footnotetext{
${ }^{10}$ Grupo Globo muda formato de Craque do Jogo e pede desculpas a Sidão. Disponível em: encurtador.com.br/aeFGV. Acesso em: 13 jul. 2019.
} 
complexas que as lógicas da sociedade dos meios, uma vez que vão além dos processos interacionais estabelecidos pelas instituições de mídia.

Foi possível demonstrar que, na sociedade em midiatização, os processos interacionais fluem de forma rizomática, reticular, por distintas plataformas midiáticas, complementando-se, retroalimentando-se, contrapondo-se e reforçando-se. Esse processo de midiatização, que implica necessariamente a articulação de distintas plataformas, inclusive com interações face a face, parece se inscrever em uma sociedade em midiatização.

Do ponto de vista epistemológico, a análise dos cinco casos empíricos chamou-nos atenção para o desafio de construirmos novos operadores interpretativos a fim de compreender os processos de interação na contemporaneidade, fenômenos esses não lineares, mas incertos, incompletos e imprevisíveis, notadamente os casos relacionados às manifestações de protesto ao assassinato de Marielle Franco (ancorado no regime do ajustamento) e à participação de Eduardo Bolsonaro no programa Mega Senha da RedeTV, que, de forma inesperada, associou a palavra livre ao nome do ex-presidente Lula, considerado um dos adversários políticos do PSL. O caso Sidão evidenciou que estamos vivendo um processo de transição entre a sociedade dos meios e a sociedade midiatizada e, sobretudo, a necessidade de ampliarmos os estudos empíricos e enriquecermos o arcabouço teórico acerca da midiatização e suas distintas lógicas que dê conta de compreender as articulações e tensionamentos entre os processos interacionais na contemporaneidade.

\section{Referências}

BRAGA, J. L. Mediatização como processo interacional de referência. Animus, Santa Maria, v. 5, n. 2, p. 9-35, jul./dez. 2006.

BRAGA, J. L. Lógicas da mídia, lógicas da midiatização. In: FAUSTO NETO, A. et al. (orgs.).

Relatos de Investigaciones sobre mediatizaciones. Rosário: UNR Editora, Editorial de la Universidad de Rosário, 2015. p. 15-32.

BRAGA, J. L. Sobre mediatização como processo interacional de referência. Animus, Santa Maria, v. 5, n. 2. p. 9-35, 2016.

O GLOBO. Manifestação convoca internautas para ato em memória de Marielle e Anderson nesta segunda-feira. 0 Globo, 1 abr. 2018. Disponível em: https://cutt.ly/Ad8y0IP . Acesso em: 22 jul. 2019.

FAUSTO NETO, A. Epistemologia do Zigue-Zague. In: FERREIRA, J.; PAOLIELLO, F. J.; SIGNATES, L. (orgs.). Estudos de Comunicação: transversalidades epistemológicas. São Leopoldo: Editora Unisinos, 2010. p. 79-100. 
FAUSTO NETO, A. Fragmentos de uma "analítica" da midiatização. MATRIZes, São Paulo, n. 2, p. 89-105, abr. 2008.

FRANCO, M. Mais um homicídio de um jovem que pode estar entrando para a conta da PM. Matheus Melo estava saindo da igreja. Quantos mais vão precisar morrer para que essa guerra acabe?. Rio de Janeiro, 13 mar. 2018. Twitter: @mariellefranco. Disponível em: https://twitter.com/mariellefranco/status/973568966403731456 Acesso em: 30 jul. 2019.

GUARANÁ ANTARCTICA [canal do Youtube]. Seleção Feminina é \#CoisaNossa. 2019. 1 vídeo digital (1:00 min). Disponível em: https://youtu.be/8wsDd_MqXwM. Acesso em: 22 jul. 2019.

LANCE. Após incentivar voto em Sidão, canal 'Desimpedidos' pede desculpas ao goleiro do Vasco. Lance, Rio de Janeiro, 13 maio 2019. Disponível em: https://cutt.ly/nd8yKqJ. Acesso em: 22 jul. 2019.

LANDOWSKI, E. Entre Comunicação e Semiótica, a interação. Parágrafo, São Paulo, v. 4, n. 2, p. 207-217, jul./dez. 2016.

LANDOWSKI, E. Interações arriscadas. São Paulo: Estação das Letras e Cores, 2014.

LANDOWSKI, E. Passions sans nom. Paris: Presses Universitaires France, 2004.

MATTOS, M. A.; MENDES, C. M., SALGADO, T. B. P. Interações midiatizadas: aproximações entre midiatização e regimes de interação e sentido. Galáxia, São Paulo, 2021. No prelo.

AUDIÊNCIA CARIOCA. Sidão, o 'Craque do Jogo': da brincadeira à falta de respeito. Entenda o caso!. Audiência Carioca, 13 maio 2019. Disponível em: https://cutt.ly/Md8yT4g. Acesso em: 22 jul. 2019.

O GLOBO. Eduardo Bolsonaro cita 'Lula' como dica para 'livre' em programa de TV. 0 Globo, 19 maio 2019. Disponível em: https://cutt.ly/1d8yvky. Acesso em: 22 jul. 2019.

OLIVEIRA, R. C. A.; GARCIA, C. C. Marielle, presente! Genocídio juvenil, feminismo e a vida dos negros e negras das favelas do Rio de Janeiro: a luta da vereadora brutalmente assassinada. Revista Latinoamericana de Ciencias Sociales, Niñez y Juventud, Manizales, Colombia - v. 16, n. 2, p. 1078-1086, julio, dez. 2018.

TINDER [aplicativo]. Exemplo de interface. Tinder, 2019. Disponível em: https://tinder.com/?lang=pt. Acesso em: 22 jul. 2019.

TWITTER [rede social]. Texto de Tweets de internautas. Twitter, 2019. Disponível em: https://twitter.com/Twitter. Acesso em: 22 jul. 2019.

ZILBERBERG, C. Elementos de semiótica tensiva. São Paulo: Ateliê, 2011. 


\title{
Mediatization and its logics: analysis of cases based on regimes of meaning and interaction
}

\begin{abstract}
This paper aims to analyze the possible articulations between the regimes of meaning and the perspectives of mediatization and their logics. The first is centered on the logic of media functioning, the second, on the logic of social processes in their imbrication with mediatization processes, called logics of mediatization. Based on empirical case studies regarding the four regimes of meaning and interaction formulated by the sociosemiotician Eric Landowski (2014) - programming, manipulation, adjustment and accident - we seek to broaden the interpretive framework about the processes of mediatizated interaction by means of the interface between those perspectives of mediatization and sociosemiotics in the context of contemporary mediatized society.
\end{abstract}

\section{Keywords}

Mediatic logics. Mediatization logics. Regimes of meaning and interaction. Sociosemiotics.

\section{Autor correspondente}

Conrado Moreira Mendes

conradomendes@yahoo.com.br

\section{Como citar}

MENDES, Conrado Moreira; MATTOS, Maria Ângela; MARICATO, André Vianna; PRIMO, Marcelle; VITI, Mariana; ALVES, Ranier. A midiatização e suas lógicas: análise de casos à luz dos regimes de interação e sentido. Intexto, Porto Alegre, n. 52, e-94707, jan./dez. 2021. DOI: http://dx.doi.org/10.19132/18078583202152.94707

Recebido em 22/07/2019

Aceito em 05/02/2020

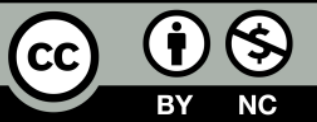

